\title{
Initial Development of Acrocarpus fraxinifolius in Function of Soil Preparation and Phosphate Mineral Fertilization
}

\author{
Geisislaine do Carmo Reis Araujo ${ }^{1}$ \\ Rodolfo Soares de Almeida ${ }^{1}$ (C) \\ Lucas Vieira dos Santos ${ }^{1}$ \\ Anatoly Queiroz Abreu Torres ${ }^{1}$ \\ Oclizio Medeiros das Chagas Silva ${ }^{1}$ \\ Lucas Amaral de Melo $^{1}$ \\ Nelson Venturin ${ }^{1}$
}

${ }^{1}$ Universidade Federal de Lavras (UFLA), Departamento de Ciências Florestais, Lavras, MG, Brasil.

\begin{abstract}
Acrocarpus fraxinifolius stands out due to its uses in the timber industry and rapid growth. However, information is scarce regarding its fertilization. We aim to understand how soil preparation and phosphorus doses affect $A$. fraxinifolius initial development. The experimental design used was a randomized block design in a $2 \times 5$ factorial scheme, consisting of two types of soil tillage (minimum and conventional) and five doses of phosphorus $(P)(0,50$, 100,150 , and $200 \mathrm{~g}$ of simple superphosphate) with four replications, and plots formed by two plants. The measurement occurs at 30 and 210 days after planting, assessing the height and diameter at the stem height. Initially, the minimum tillage provided had a higher average height and diameter. However, conventional tillage, acidity correction, and fertilization with $108 \mathrm{~g}$ of simple superphosphate per plant resulted in Acrocarpus fraxinifolius plants with better growth at 210 days after planting.
\end{abstract}

Keywords: Phosphate fertilizers, field preparation, forest plantations, plant nutrition, fertilizer application.

\section{INTRODUCTION AND OBJECTIVES}

The introduction of forest species with higher yield potential is strategical for Brazilian forestry. A species from the tropical regions of Asia that are gaining prominence worldwide is the Acrocarpus fraxinifolius Arn., mainly due to its rapid growth, the potential for agroforestry systems, and the diversity of its uses in the wood industry, wood panels, and paper industry (Nath et al., 2011).

Belonging to the family Fabaceae and subfamily Caesalpinioideae, it is popularly known as Indian Cedar, Guijarra, Lazcar, Mundane, Pink Cedar, and Shingle tree. Despite being cultivated in agroforestry systems with pepper, corn, and beans in India and Mexico, its main application is shading coffee and tea crops (Nath et al., 2011). The productivity of the species in Brazil is in the range of 10 to $40 \mathrm{~m}^{3}$ ha.year1 with small plantations located in the south and southeast regions in spacings of $3 \times 3 \mathrm{~m}$ (Venturin et al., 2014). Despite the potential, scientific studies on nutrition and fertilization are rare, and there is no study at field preparation for forest plantation for Acrocarpus fraxinifolius.

Tropical soils, in general, have low natural fertility, so fertilization is necessary since it is not always able to provide all the nutrients that plants demand (Machado et al., 2011), especially the nutrients soils intended for forest plantations. Thus, the availability of nutrients in the soil is one of the factors that influence the productivity of reforestation with fast-growing species, since these are necessary for many physiological processes of plants, controlling their growth and development (Rovedder et al., 2013).

The lack of phosphorus (P) in Brazilian soils is due to the source material and the strong interaction of $\mathrm{P}$ with soil colloids, with less than $0.1 \%$ of this element found in the soil solution (Nunes et al., 2011). Phosphorus deficiency in plants can reduce respiration and photosynthesis, delaying or paralyzing cell growth, causing a decline in biomass and seed 
production, delayed sprouting, reduced leaf emergence, and secondary root development (Veigas et al., 2013). Acrocarpus fraxinifolius seedlings presented a smaller leaf area, inhibition of axial buds, increased branching, and leaf chlorosis when in a phosphorus deficit environment, resulting in smaller and less vigorous plants (Munguambe et al. 2017). There is a positive response in growth after phosphate fertilization for several forest species such as Eucalyptus dunnii and Eucalyptus benthamii (Stahl et al., 2013); Cassia grandis (Freitas et al., 2017).

Another factor in the establishment and initial growth of forest plantations is soil preparation. It alters the density, macroporosity, microporosity, and resistance to penetration (Silva et al., 2011a). The soil preparation techniques aim to maximize the growth of the root system through more or less localized soil tillage, facilitating the absorption of water and nutrients, also eliminating unwanted plants near the seedlings (Gonçalves et al., 2017).

On a conventional soil tillage system, there is an intense intervention in the total area of the soil, with cutting, turning, and inversion of ridges, thus increasing the pore volume, the degradation of organic matter, and the reduction of density (Lisboa et al., 2012). On the other hand, in the minimum cultivation system, revolving occurs only in the planting lines, thus keeping cover residues in the soil as a form of protection, preserving the structure and soil moisture (Sales et al., 2016).

Based on the behavior of other species, the hypothesis is that phosphorus fertilization is necessary and, soil preparation in minimal cultivation brings better benefits. Both topics are essential to support the use of the species for forest plantation and reduce the gap regarding fertilization and suitable soil preparation techniques. This work aimed to evaluate the effect of soil preparation and different doses of phosphorus on the initial growth of Acrocarpus fraxinifolius.

\section{MATERIALS AND METHODS}

The experimental area is in Lavras, Minas Gerais at the coordinates $21^{\circ} 13^{\prime} 47.615^{\prime \prime} \mathrm{S} ; 44^{\circ} 59^{\prime} 9.899^{\prime \prime} \mathrm{W}$. The climate is Cwb, according to Köppen's classification, characterized by tropical altitude with mild summers, an average annual temperature of $19,6^{\circ} \mathrm{C}$, average annual precipitation of $1511 \mathrm{~mm}$, average annual relative humidity of $76.2 \%$, and total annual evaporation of $901.1 \mathrm{~mm}$ (Alvares et al., 2013). The predominant biome is Savanna (Cerrado), and the soil is Cambisol Haplic Dystrophic (EMBRAPA, 2013). Table 1 displays the main results of the soil chemical analysis before preparation.

Table 1. Chemical analysis of dystrophic cambisol at a depth of $0-20 \mathrm{~cm}$ in Lavras-MG.

\begin{tabular}{|c|c|c|c|c|c|c|c|c|c|c|c|c|c|c|}
\hline \multirow{2}{*}{ pH } & MO & K & $\mathbf{P}$ & $\mathrm{Ca}$ & $\mathrm{Mg}$ & Al & $\mathrm{H}+\mathrm{Al}$ & V & $\mathrm{Zn}$ & $\mathrm{Fe}$ & Mn & $\mathrm{Cu}$ & B & S \\
\hline & $\mathrm{dag} / \mathrm{Kg}$ & \multicolumn{3}{|c|}{$\mathrm{mg}^{\mathrm{dm}} \mathrm{m}^{-3}$} & \multicolumn{3}{|c|}{$\mathrm{cmol}_{\mathrm{dm}} \mathrm{dm}^{-3}$} & $\%$ & \multicolumn{6}{|c|}{$\mathrm{mg} \cdot \mathrm{dm}^{-3}$} \\
\hline 6.2 & 1.19 & 45.3 & 1.6 & 1.3 & 0.62 & 0.11 & 2.32 & 46.7 & 0.5 & 156.7 & 12.5 & 0.96 & 0.04 & 26.3 \\
\hline
\end{tabular}

* MO: organic matter; V: base saturation index.

The soil preparation consisted of two different approaches: (1) conventional tillage, where limestone was applied superficially, followed by plowing, harrowing, limestone incorporation, and furrowing, and (2) minimal cultivation, where only the limestone application was carried out on the surface, followed by furrowing, considering a depth of $20 \mathrm{~cm}$.

The doses of $\mathrm{P}$ used, 0, 50, 100, 150, and $200 \mathrm{~g}$ per pit, were calculated based on the $\mathrm{P}$ contents expressed in the soil analysis (Table 1) and based on the proposal by Barros \& Novais (1999) for eucalyptus. The source of $\mathrm{P}$ was the simple superphosphate $\left(18 \% \mathrm{P}_{2} \mathrm{O}_{5}\right)$.

The experimental design was a randomized complete block in a $2 \times 5$ factorial scheme, composed of two types of soil preparation (conventional preparation and minimum cultivation) and five doses of $\mathrm{P}(0,50,100,150$, and $200 \mathrm{~g}$ per pit), with four replications, and plots formed by two plants.

The arrangement used was $6 \times 1.5 \mathrm{~m}$, with the phosphate fertilizer was incorporated into the soil in lateral holes after planting. At 180 days after planting, was applied a top dressing with $60 \mathrm{~g}$ of NPK, 10:00:20 formulation. At 30 and 210 days after planting, were measured the height and diameter at the ground level.

The data obtained were submitted to the Shapiro-Wilk normality tests. Subsequently, the analysis of variance $p<0.05$, when detected a difference, was performed the Tukey test $p<0.05$, and regression analysis, using the SISVAR software (FERREIRA, 2019).

\section{RESULTS AND DISCUSSION}

Individuals of Acrocarpus fraxinifolius had general averages of $68.10 \mathrm{~cm}$ in height and $12.33 \mathrm{~mm}$ in diameter of the collar at 210 days, with an average increase of $46.24 \mathrm{~cm}$ in height and $9.09 \mathrm{~mm}$ in diameter over a period of 6 months. There was a significant interaction $(p<0.05)$ between phosphorus doses and soil preparation for height and stem diameter at 210 days after fertilization, as well as the effect of the type of soil preparation, influenced the growth in height and diameter of the stem at both evaluated ages (Table 2). The experimental precision (CV\%) remained between 10.59 and $29.22 \%$, considered adequate for field experiments. 
Table 2. Analysis of variance for height and diameter at the soil base of Acrocarpus fraxinifolius seedlings at 30 and 210 days after planting.

\begin{tabular}{|c|c|c|c|c|c|}
\hline \multirow{3}{*}{ Source of Variation } & \multirow{3}{*}{ Df } & \multicolumn{4}{|c|}{ Sum of Squares } \\
\hline & & \multicolumn{2}{|c|}{ Height } & \multicolumn{2}{|c|}{ Stem diameter } \\
\hline & & 30 days & 210 days & 30 days & 210 days \\
\hline Block & 3 & 1.88 & 158.97 & 0.1 & 10.3 \\
\hline Phosphorus (P) & 4 & 12.14 & 810.32 & 0.19 & 17.39 \\
\hline Soil Preparation & 1 & $336.69^{*}$ & $19891.6^{*}$ & $5.48^{*}$ & $770.09^{*}$ \\
\hline Phosphorus * Soil Preparation & 4 & 15.53 & $1045.36^{*}$ & 0.25 & $23.39^{*}$ \\
\hline Residual & 27 & 5.36 & 383.79 & 0.23 & 12.76 \\
\hline Mean & - & $21.86 \mathrm{~cm}$ & $68.1 \mathrm{~cm}$ & $3.24 \mathrm{~mm}$ & $12.23 \mathrm{~mm}$ \\
\hline $\mathrm{CV}(\%)$ & - & 10.59 & 28.77 & 14.91 & 29.22 \\
\hline
\end{tabular}

${ }^{*}$ Significant by the $\mathrm{F}$ test $p<0.05$.

The response to soil preparation varied according to age. The minimum cultivation (2) provided the highest growth in height and diameter of the stem at 30 days. However, after 210 days, seedlings planted under conventional tillage (1) showed superior growth in the evaluated characteristics (Table 3). Conventional tillage at 210 days after fertilization provided an increase of $97.84 \%$ in height and $111.84 \%$ in diameter at the ground level of the Acrocarpus fraxinifolius seedling.

Table 3. Average height and diameter at the soil base of Acrocarpus fraxinifolius, at 30 and 210 days after planting, by the type of soil preparation.

\begin{tabular}{lccccccccc}
\multicolumn{1}{c}{ Soil preparation } & \multicolumn{3}{c}{ Height $(\mathbf{c m})$} & \multicolumn{3}{c}{ Stem diameter $(\mathbf{m m})$} \\
\cline { 2 - 9 } & $\mathbf{3 0}$ days & & $\mathbf{2 1 0}$ days & & $\mathbf{3 0}$ days & \multicolumn{2}{c}{$\mathbf{2 1 0}$ days } \\
Conventional & 18.96 & $\mathrm{~b}$ & 90.4 & $\mathrm{a}$ & 2.87 & $\mathrm{~b}$ & 16.61 & $\mathrm{a}$ \\
Minimum Cultivation & 24.76 & $\mathrm{a}$ & 45.8 & $\mathrm{~b}$ & 3.61 & $\mathrm{a}$ & 7.84 & $\mathrm{~b}$ \\
\hline
\end{tabular}

Means followed by the same letter, in the column, do not differ from each other, by the Tukey test $p<0.05$.

The interaction between phosphorus doses and type of soil tillage found at 210 days after fertilization show that, for both height (Figure 1) and stem diameter at ground level (Figure 2), Acrocarpus fraxinifolius seedlings responded in similar ways. The soil preparation in minimum cultivation (2) did not show a response regarding the increase in the applied phosphorus dose, therefore there is no significant relationship between these parameters in both characteristics.

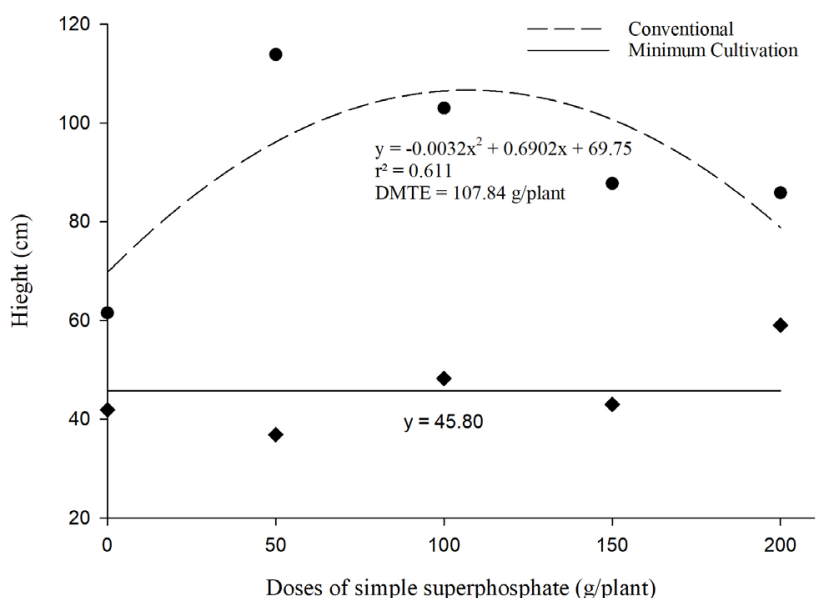

Figure 1. Height of seedlings of Acrocarpus fraxinifolius, 210 days after planting, depending on the type of soil preparation and the doses of simple superphosphate.
The conventional tillage (1) has a quadratic regression for the phosphorus dose for height and the stem diameter.

The maximum point for the phosphorus dose was approximately $108 \mathrm{~g} /$ plant. Thus, fertilization with a dose of $108 \mathrm{~g} /$ plant of simple superphosphate per pit resulted in the best average height $(106.96 \mathrm{~cm})$ and diameter at ground level (19.36 mm) in Acrocarpus fraxinifolius seedlings when in corrected soil.

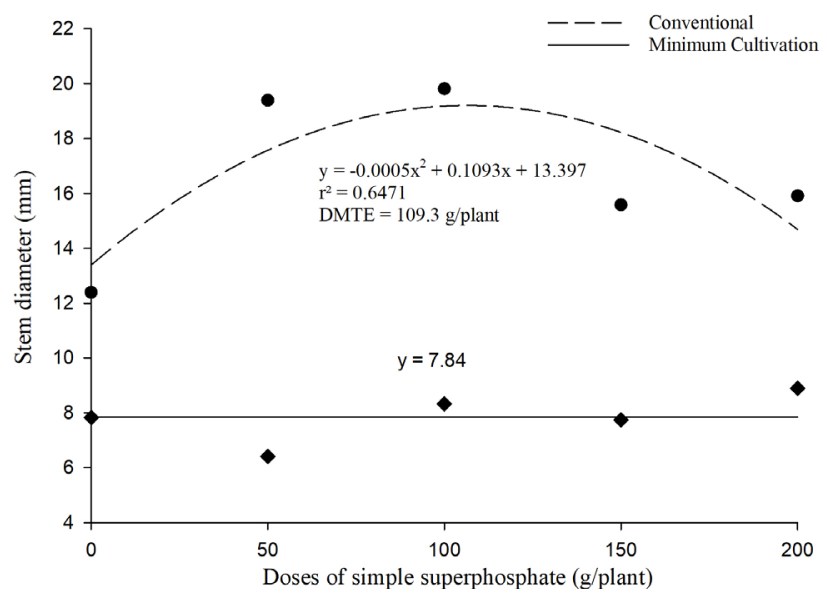

Figure 2. Diameter at soil base of the Acrocarpus fraxinifolius seedling, 210 days after planting, depending on the type of soil preparation and the doses of simple superphosphate. 
The results make it clear that the tillage of the soil only in the cultivation line, featuring minimal cultivation, was efficient in promoting the initial growth of Acrocarpus fraxinifolius seedlings in the first month after planting. Minimum cultivation provides higher infiltration rates and lower rates of water loss in the soil when compared to other types of soil preparation that involve higher disturbance and changes in soil structure (Silva et al. 2011b). Thus, the result found may be associated with minimal cultivation provided better moisture conditions for the plants in the initial evaluation period. Soil management is one of the practices that affect the water infiltration capacity in the soil and, consequently, the availability of nutrients and satisfaction of the water demand for plants (Pereira \& Rodrigues, 2013).

At 210 days after planting, the results changed from the initial evaluation, with plants from the area with conventional tillage showing superior performance. With soil decompaction, the soil has a low resistance to penetration, and a myriad of pores, becoming more suitable for the establishment and development of forest species. Prevedello et al. (2013) highlight soil decompaction as one of the silvicultural practices that increase productivity.

Thus, at 210 days, through the development of the plants, expansion of the capacity to explore larger volumes and depths of soil by the roots and the occurrence of rain, the area subjected to practices of plowing, harrowing, and limestone incorporation possibly provided the plants better conditions for this exploration, which resulted in better seedling performance. Similar results were found by Prevedello et al. (2013) when they found that the growth of Eucalyptus grandis was higher in areas where soil tillage was carried out as a method of soil preparation.

The phosphorus application was significant with conventional tillage at the second evaluation (Figures 1 and 2). This relation is possibly related to the practice of incorporating limestone and consequent correction of soil $\mathrm{pH}$. According to Fidalski et al. (2015), the limestone application increases the negative charges in the soil, thus increasing the availability and efficiency of nutrients such as phosphorus. In line with these results, Dias et al. (2015) report that the practice of liming associated with the application of phosphate resulted in the best performance of seedlings of Eucalyptus dunnii and Eucalyptus benthamii.

Although the plants have a high demand for phosphorus in the early stages of development, which justifies its application at the time of implantation (Munguambe et al., 2017), for some forest species, its effect has been verified not only from the first year after planting (Vasconcelos et al., 2017). This fact indicates the importance of continuous evaluations of Acrocarpus fraxinifolius plants and, consequently, the effect of phosphorus on seedling development for an extended period.
A better understanding of how the species respond to soil preparation and phosphorus fertilization may lay the foundation to encourage the use of Acrocarpusfraxinifolius as an alternative species to Brazilian forestry. Since there is little information about the species, new studies are necessary to help define the recommendation of ideal fertilization to maximize the productivity of the species.

\section{CONCLUSIONS}

1. The conventional soil preparation with the superficial application of limestone, followed by plowing, harrowing, limestone incorporation, and furrow was superior to the minimum cultivation.

2. Phosphate dosage interacts with the type of soil preparation. The dosage of $108 \mathrm{~g}$ of simple superphosphate per hole in conventional soil preparation is recommended for superior growth of Acrocarpus fraxinifolius seedlings at 210 days after planting in the implantation model of this work.

\section{SUBMISSION STATUS}

Received: 25 Sep. 2021

Accepted: 25 Nov. 2021

Associate editor: Marcos Gervásio Pereira (1)

\section{CORRESPONDENCE TO}

\section{Rodolfo Almeida}

Campus universitário, CEP 37200-900, Lavras, MG, Brasil. e-mail: rodoxalmeida1991@gmail.com

\section{AUTHORS' CONTRIBUTIONS}

Geisislaine do Carmo Reis Araujo: Conceptualization (Supporting); Data curation (Lead); Formal analysis (Equal); Methodology (Equal); Project administration (Equal); Validation (Equal); Writing - original draft (Lead); Writing - review \& editing (Supporting).

Rodolfo Soares de Almeida: Data curation (Supporting); Formal analysis (Equal); Investigation (Equal); Methodology (Supporting); Validation (Equal); Writing - original draft (Supporting); Writing - review \& editing (Lead).

Lucas Vieira dos Santos: Data curation (Supporting); Formal analysis (Supporting); Methodology (Supporting); Project administration (Equal); Writing - review \& editing (Supporting).

Anatoly Queiroz Abreu Torres: Data curation (Supporting); Investigation (Supporting); Methodology (Supporting); Project administration (Supporting); Writing - review \& editing (Supporting). Oclizio Medeiros das Chagas Silva: Data curation (Supporting); Formal analysis (Supporting); Investigation (Equal); Methodology (Equal); Project administration (Supporting);

Validation (Supporting); Writing - review \& editing (Supporting). Lucas Amaral de Melo: Conceptualization (Lead); Methodology (Lead); Project administration (Lead); Resources (Lead); Supervision (Lead); Validation (Lead); Visualization (Lead); Writing - review \& editing (Supporting).

Nelson Venturin: Conceptualization (Lead); Project administration (Equal); Resources (Equal); Supervision (Lead); Validation (Lead); Visualization (Lead); Writing - original draft (Equal). 


\section{REFERENCES}

Alvares, CA, Stape JL, Sentelhas PC, Gonçalvez JLM, Sparovek G. Koppen's climate classification map for Brazil. Meteorologische Zeitschrift 2013; 22(6): 711-728. DOI: 10.1127/0941-2948/2013/0507

Barros Nf, Novais RF. Eucalipto. In: Ribeiro AC, Guimaraes PT, Alvarez VH, editor. Recomendações para uso de corretivos e fertilizantes em Minas Gerais. 5a Aproximação. Comissão de Fertilidade do Solo do estado de Minas Gerais, Viçosa: CFSEMG, 1999.

Dias LPR, Gatiboni LC, Brunetto G, Simonete BB. Eficiência relativa de fosfatos naturais na adubação de plantio de mudas de Eucalyptus dunnii Maiden e Eucalyptus benthamii Maiden et Cambage em solo sem e com calagem. Ciência Florestal 2015, 25(1):37-48. DOI: http:// dx.doi.org/10.5902/1980509817443

Empresa Brasileira De Pesquisa Agropecuária - EMBRAPA. Centro Nacional de Pesquisa de Solos. Sistema brasileiro de classificação de solos. 3.ed. Rio de Janeiro, 2013.

Ferreira DF. SISVAR: A computer analysis system to fixed effects split plot type designs. Revista Brasileira de Biometria 2019, 37(4):529535. DOI: https://doi.org/10.28951/rbb.v37i4.450.

Fidalski J, Yagi R, Tormena CA. Revolvimento Ocasional e Calagem em Latossolo Muito Argiloso em Sistema Plantio Direto Consolidado. Revista Brasileira de Ciências do Solo 2015, 39,(5):1483-1489. DOI: https://doi.org/10.1590/01000683rbcs20140428

Freitas ECS, Paiva HN, Leite HG, Neto Oliveira SN. Crescimento e qualidade de mudas de Cassia grandis Linnaeus em resposta a adubação fosfatada e calagem. Ciência Florestal 2017, 27(2):509519. DOI: https://doi.org/10.5902/1980509827732

Gonçalves SB, Lopes ES, Fiedler NC, Cavalieri-Polizeli KMV, Stahl J. Resistência do solo a penetração em diferentes profundidades de subsolagem. Nativa 2017, 5(3):224-229. DOI: 10.31413/nativa. v5i3.4109

Lisboa BB, Vargas LK, Silveira AO, Martins AF, Selbach PA. Indicadores microbianos de qualidade do solo em diferentes sistemas de manejo. Revista Brasileira de Ciência do Solo 2012, 36:33-43. DOI: https://doi.org/10.1590/S0100-06832012000100004

Machado VJ, Souza CHE, Andrade BB, Lana RMQ, Korndorfer $\mathrm{GH}$. Curvas de disponibilidade de fósforo em solos com diferentes texturas após aplicação de doses crescentes de fosfato monoamônico. Bioscience Journal 2011, 27(1):70-76.

Munguambe JF, Venturin N, Silva MLS, Carlos L, Silva DSN, Farias ES et al. Effect of deprivation of selected single nutrients on biometric parameters of cedar seedlings (Acrocarpus fraxinifolius) grown in nutritive solution. African Journal of Agricultural Research 2017, 12(39):2886-2894. DOI: https://doi.org/10.5897/ AJAR2017.12384

Nath CD, Pélissier R, Ramesh BR, Garcia C. Promoting native trees in shade coffee plantations of southern India: comparison of growth rates with the exotic Grevillea robusta. Agroforest System 2011, 83: 107-119. DOI: https://doi.org/10.1007/s10457-011-9401-8

Nunes RDS, Sousa DMGD, Goedert WJ, Vivaldi LJ. Distribuição de fósforo no solo em razão do sistema de cultivo e manejo da adubação fosfatada. Revista Brasileira de Ciência do Solo 2011, 35(3):877-888.

Pereira LS, Rodrigues AM. Sistemas de Manejo de Cultivo Mínimo e Convencional: Análise Temporal da Dinâmica Hidrológica do Solo e da Variação Produtiva em Ambiente Serrano. Revista Brasileira de Geografia Física 2013, 6(6):1658-1672. DOI: https:// doi.org/10.5935/1984-2295.20130050

Prevedello J, Kaiser DR, Reinert DJ, Vogelmann ES, Fontanela E, Reichert JJ. Manejo do solo e crescimento inicial de Eucalyptus grandis Hill ex Maiden em argissolo. Ciência Florestal 2013, 23(1):129-138. DOI: https://doi.org/10.5902/198050988447

Rovedder APM, Suzuki LEAS, Dalmolin RSD, Reichert JM, Schenato RB. Compreensão e aplicabilidade do conceito de solo florestal. Ciência Florestal 2013, 23(3):517-528. DOI: http://dx.doi. org/10.5902/1980509810563

Sales RP, Portugal AF, Moreira JAA, Kondo MK, Pegoraro RF. Qualidade física de um latossolo sob plantio direto e preparo convencional no semiárido. Revista Ciência Agronômica 2016, 47:429-438. DOI: https://doi.org/10.5935/1806-6690.20160052

Silva AR, Dias Júnior MS, Leite FP. Avaliação da intensidade de tráfego e carga de um forwarder sobre a compactação de um Latossolo Vermelho-amarelo. Revista Árvore 2011a, 35(3):547-554. DOI: https://doi.org/10.1590/S0100-67622011000300017

Silva MA, Silva MLN, Curi N, Avanzi JC, Leite FP. Sistemas de manejo em plantios florestais de eucalipto e perdas de solo e água na região do Vale do Rio Doce, MG. Ciência Florestal 2011b, 21(4): 765-776. DOI: https://doi.org/10.5902/198050984520

Stahl J, Ernani PR, Gatiboni LC, Chaves DM, Neves CU. Produção de massa seca e eficiência nutricional de clones de Eucalyptus dunni e Eucalyptus benthamii em função da adição de doses de fósforo ao solo. Ciência Florestal 2013, 23(2):287-295. DOI: https://doi. org/10.5902/198050989275

Vasconcelos RT, Valeri SV, Cruz MCP, Barbosa JC, Barreto VCM. Fertilização fosfatada na implantação de Khaya senegalensis A. Juss. Scientia Forestalis 2017, 45(116): 641-651. DOI: https://dx.doi. org/10.18671/scifor.v45n116.05

Veigas IJM, Sousa GO, Silva AF, Carvalho JG, Lima MM. Composição mineral e sintomas visuais de deficiências de nutrientes em plantas de pimenta-longa (Piper hispidinervum C. DC.). Acta Amazonica 2013, 43(1):43-50. DOI: https://doi.org/10.1590/S004459672013000100006

Venturin N, Carlos L, Souza PA, Macedo RLG, Venturin RP, Higashikawa EM. Desempenho silvicultural de Acrocarpus fraxinifolius Wight em função de diferentes espaçamentos e idades. Cerne 2014, 20(4):629-636. DOI: https://doi.org/10.1590/010477 6020142004668 